\title{
QUANTITATIVE PHYTOCHEMICAL SCREENING, THIN-LAYER CHROMATOGRAPHY ANALYSIS, HIGH-PERFORMANCE THIN-LAYER CHROMATOGRAPHY FINGERPRINTING, AND ANTIOXIDANT ACTIVITY OF LEAVES OF DIOSPYROS MONTANA (ROXB.)
}

\author{
ABHIJEET V PURI* \\ Department of Pharmacognosy, St. John Institute of Pharmacy and Research Vevoor, Palghar, Maharashtra, India. \\ Email: avpuri@rediffmail.com
}

Received: 17 September 2018, Revised and Accepted: 30 October 2018

\begin{abstract}
Objective: The objective of this study was to investigate important phytochemical constituents and antioxidant potential of Diospyros montana Roxb. leaves belonging to the family Ebenaceae.

Methods: Leaves were exhaustively extracted with ethanol and fractionated into petroleum ether, chloroform, and ethyl acetate extracts. The various fractions were further analyzed for phytochemical composition and concentration-dependent antioxidant activity using conventional methods and high-performance thin-layer chromatography (HPTLC) fingerprinting. Since leaves contained phenolic compounds, extracts were evaluated for total phenolic content, flavonoids contents, and in-vitro antioxidant activity. Antioxidant potential was assessed using parameters such as superoxide radical scavenging, nitric oxide inhibition, and $\beta$-carotene/linoleic acid antioxidant activity.
\end{abstract}

Results: Primitive phytochemical investigation highlighted the presence of steroids, saponins, flavonoids, alkaloids, and tannins which were confirmed by TLC and HPTLC fingerprinting. The antioxidant activity of leaf extracts decreased in the following order ethyl acetate > ethanolic > chloroform > petroleum ether and it was comparable with standards such as ascorbic acid and butylated hydroxytoluene.

Conclusion: The present study concludes that the ethanolic extract and fractions of $D$. montana (Roxb.) leaves have prominent antioxidant activity comparable to standards. Therefore, $D$. montana (Roxb.) leaves may be used as a probable source of natural antioxidants in the pharmaceutical industry.

Keywords: Diospyros montana Roxb., Pharmacognostic, Phytochemical, Physiochemical analysis, Antioxidant, Radical scavenging.

(c) 2019 The Authors. Published by Innovare Academic Sciences Pvt Ltd. This is an open access article under the CC BY license (http://creativecommons. org/licenses/by/4. 0/) DOI: http://dx.doi.org/10.22159/ajpcr.2019.v12i2.29738

\section{INTRODUCTION}

In most recent decades there has been a wide improvement in zeal for drug discovery from a natural origin in uniqueness to the synthetics which are seen as unsafe to general population and environment. Medicinal plants and traditional systems of remedy have been always associated as therapeutic plants are the backbone of these systems. India has a rich natural heritage legacy of traditional systems of medicine the progression of these traditional systems of medicines with the perspectives of safety, efficacy, and quality will urge to defend the traditional heritage[1]. Ebenaceae are a group of blooming plants, which includes ebony and persimmon. The family has species of trees and bushes in two genera, Diospyros and Euclea which are widespread mostly in tropics and subtropics [2]. The genus Diospyros montana (Roxb.) (Ebenaceae) was found in subtropical and tropical territories of the China, India, Indonesia, and the Malay Peninsula. The genus Diospyros consists of 700 species of deciduous and evergreen trees, shrubs, and small bushes out of which 59 of which are spread in India [3]. D. montana (Roxb.) is a little tree with slim stem and smooth bark; youthful shoots are glabrous or pubescent. Leaves are alternate, ovate to oblong or elliptical acute or sub acuminate with base usually rounded, softly pubescent or tomentose when young ultimately glabrescent [4]. The plant and parts, particularly the natural product have been utilized as an anti-inflammatory and antipyretic agent in numerous traditional systems of medicine. Literature reveals phytochemical and pharmacological studies on 13 Diospyros species [5]. D. montana (Roxb.) exhibits anthelmintic, anticancer, anti-inflammatory, antimalarial, antiviral, prostaglandin synthesis inhibitory, hypolipidemic, antitumor, and antileukemic activity. In
Indian ethnomedicinal, this plant is locally named as Ebony and its bark is used in therapy of jaundice and gum and is prescribed in tuberculosis while roots are used as an abortifacient [6]. Chemistry of free radical is complicated and it caused a noteworthy impediment in the identification of free radical scavenging agent. To withstand this issue, the potential antioxidant agent is evaluated for in vitro radical scavenging model, and such methodologies develop the possibility of antioxidant activity [7]. The biological systems have antioxidant defense mechanism which safeguards it against oxidative damages. However, this natural antioxidant mechanism can be incompetent; therefore, nutritional ingestion of antioxidant combinations is essential. Phytoconstituents contain a wide array of free radical scavenging molecules such as flavonoids, vitamins, polyphenols, and terpenoids that are rich in antioxidant activity [8]. Free radical reactions have been implicated in the pathology of many human diseases including atherosclerosis, ischemic heart disease, the aging process, inflammation, diabetes, immune depression, neurodegenerative condition, and other degenerative disorders [9]. Free radicals are formed in tissue cells by many endogenous and exogenous reasons such as ionizing radiation, chemical, and metabolites [10]. These free radicals, which are atoms or molecules with an unpaired electron, are capable of reversibly or irreversibly damaging compounds of all biochemical classes, including nucleic acids, proteins, and free amino acids, lipids and lipoproteins, carbohydrates, and connective tissue macromolecules [11]. Drugs with multiple mechanisms of protective action, including antioxidant properties, may be one-way forward in minimizing tissue injury in human disease [12]. The polyphenolic and flavonoid phytochemical present in the extracts appeared to be 
accountable for the antioxidant activity. Polyphenolic compounds found in plant extracts are flavonoids and phenolic acids [13]. In absorption or neutralization of free radicals, phenolics play a significant role through antioxidant activity [14]. Polyphenols and flavonoids also enhance the level of the cellular antioxidative system and induce the cytochrome P-450 resulting in detoxifying the activity of intracellular carcinogens [15]. In this present work, we expect to build up a connection between the phytoconstituents present in the leaves and its different pharmacological activities. Hence, in this work, we endeavored to investigate phytochemical constituents and antioxidant activity of the leaves of D. montana (Roxb.).

\section{METHODS}

\section{Collection of plant material}

Fresh leaves of D. montana (Roxb.) collected from neighborhood cantonment area of Belgaum district (Karnataka).

\section{Authentication of plant material}

The leaves of D. montana (Roxb.) were authenticated by Dr. B. D. Huddar at the Department of Botany Shri Kadasiddheshwar H.S. Kotambari Science Institute, Vidyanagar, Hubli, Karnataka. A specimen sample (DM-08) is deposited in the Department of Pharmacognosy, at KLES college of Pharmacy Hubli, Karnataka.

\section{Drying and size reduction of $D$. montana (Roxb.) leaves}

The leaves of D. montana (Roxb.) were cleaned to evacuate the adhered foreign material and were washed under tap water, air-dried, homogenized to the fine powder, and stored in hermetically sealed bottles.

\section{Chemicals and instruments}

All the chemicals used in this research were of analytical grade and were obtained from Loba Chemicals Limited India Mumbai, India.

\section{Preparation of extracts}

Fresh shade dried leaves of D. montana (Roxb.) were powdered and extracted with ethanol by continuous hot percolation method using a Soxhlet apparatus. The ethanolic extract was concentrated under reduced pressure using a rotary evaporator and dried in vacuum. A portion of the crude ethanolic extract was suspended in water and successively re-extracted with petroleum ether, chloroform, and ethyl acetate. After distillation, the resultant extracts were collected in a clean dry glass beaker. All fractions, including the aqueous fraction, were evaporated to dryness in a Buchi Rotary vacuum evaporator (Rotavapor R-210, Switzerland) at $40-50^{\circ} \mathrm{C}$ and the final extracts were kept at low temperature for further investigations $[16,17]$.

\section{Preliminary phytochemical analysis}

The ethanolic extract and its fractions of petroleum ether, chloroform, and ethyl acetate were subjected to phytochemical screening for detections of phytoconstituents as carbohydrates, glycosides, phytosterol steroids, triterpenoids, tannins, phenolics, alkaloids, and flavonoids present in them using standard protocols [18-21].

\section{Thin-layer chromatography (TLC)}

On the basis of the preliminary phytochemical analysis, ethanolic extract and fractions were subjected to TLC. The semi-solid extract was subjected to chromatography by taking a small amount of the extract diluted with a drop of the solvent. These extracts were analyzed as per the conventional one-dimensional ascending method using the standard procedure. In this method, pre-coated silica gel plate (Silica Gel $60 \mathrm{~F}_{245}$ ) was used. Glass capillaries were used to apply the spot on the TLC plate, approximately $1 \mu \mathrm{L}$ of sample volume applied using capillary at distance of $1 \mathrm{~cm}$ and the 3 tracks and developed in airtight chamber already saturated with the same solvent system. In the twin trough chamber with different solvent systems, chloroform:ethyl acetate acid (80:20) solvent system-I. In solvent system-II, petroleum ether:benzene $(40: 10)$ used. After pre-saturation with mobile phase, allowed to develop for $20 \mathrm{~min}$. After chromatograph was developed, plates were dried in hot air oven and subjected to visualization in UV chamber $(254,365 \mathrm{~nm})$. Here, freshly prepared anisaldehyde sulfuric acid was used as a visualizing agent. The distance traveled by phytoconstituents was noted by calculating its retention factor $\left(\mathrm{R}_{\mathrm{f}}\right)$ value, and the chromatograms were photographed $[22,23]$.

\section{High-performance TLC (HPTLC) fingerprinting}

A quantitative and qualitative analysis was performed with the assistance of HPTLC instrument. The chromatographic estimation was performed by streaking the extracts in the form of narrow bands of $6 \mathrm{~mm}$ length on the precoated silica gel $60 \mathrm{~F} 254$ aluminum TLC plate $\left(10 \mathrm{~cm}^{2}\right)$, at a consistent application rate of $150 \mu \mathrm{L} / \mathrm{s}$ and gas flow $10 \mu \mathrm{L} / \mathrm{s}$ was employed with the help of Camag $100 \mu \mathrm{L}$ syringe connected to a Nitrogen tank; using a Camag Linomat V (Camag, Muttenz, Switzerland). The space between three bands was kept $15 \mathrm{~mm}$. 1\% concentration solution of $5 \mu \mathrm{L}$ from each of the three extracts (ethanol, chloroform, and petroleum ether) was set as a spot. After spotting, the plate was subjected to linear ascending development up to a distance of about $90 \mathrm{~mm}$ in a solvent system of cyclohexane:ethyl acetate $(8: 2 \mathrm{v} / \mathrm{v})$ at Camag Twin Trough Glass Chamber, which was saturated with the same solvent system at room temperature just $30 \mathrm{~min}$ preceding the development. TLC plate was dried in flowing air at room temperature. Densitometric scanning was carried out between wavelength 256-366 $\mathrm{nm}$. The chromatograms were integrated, and regression analysis and statistical data were generated using Win-CATS evaluation software [24].

\section{Quantitative determination assays}

\section{Total flavonoid content}

The total flavonoid content was estimated using standard methods with minor modifications using quercetin as a standard. The standard solutions with the following final concentrations were prepared; 50, $100,150,200$, and $250 \mathrm{mg} / \mathrm{mL} .1 \mathrm{~mL}$ of each standard solution and extract solutions was taken into $10 \mathrm{~mL}$ volumetric flask, containing $4 \mathrm{~mL}$ of deionized water. Then, $0.3 \mathrm{~mL}$ of $10 \% \mathrm{AlCl}_{3}$ was added to the mixture. At the $6^{\text {th }}$ min, $2 \mathrm{~mL}$ of $\mathrm{NaOH}(1 \mathrm{~mol} / \mathrm{L})$ was added, and the volume was made up to $10 \mathrm{~mL}$ with distilled water. The absorbance was read at $510 \mathrm{~nm}$ UV-visible spectrophotometer. The results of the total flavonoids were expressed as quercetin equivalents. The total flavonoids content was calculated by the following formula: $\mathrm{X}=\left(\mathrm{A} . \mathrm{m}_{\mathrm{o}}\right) /$ $\left(A_{0} . m\right)$. Where " $\mathrm{X}$ " is the flavonoid content, $\mathrm{mg} / \mathrm{g}$ plant extract, " $\mathrm{A}$ " is the absorption of plant crude extract solution, " $\mathrm{o}_{\mathrm{o}}$ " is the absorption of standard quercetin solution, " $\mathrm{m}$ " is the weight of crude drug extract in $\mathrm{mg}$, and " $\mathrm{m}_{\mathrm{o}}$ " is the weight of quercetin in the solution in $\mathrm{mg}$. The assay was carried out in triplicate, and the mean values with \pm SEM are presented [25].

\section{Total phenolic content}

The total phenolic content of the crude extract and fractions was determined with the Folin-Ciocalteu reagent following the modified method. Briefly, various concentrations of test samples made in deionized water $(1 \mathrm{~mL})$ were added to $0.5 \mathrm{~mL}$ of Folin-C1ocalteu reagent (previously diluted 10 -fold with deionized water). After allowing the mixture to stand at room temperature for $5 \mathrm{~min}, 15 \mathrm{~mL}$ to $20 \%(\mathrm{w} / \mathrm{v}$ ) sodium carbonate was added. Reaction mixtures were further incubated at room temperature for $2 \mathrm{~h}$, following which absorbance at $765 \mathrm{~nm}$ was read, using a UV-visible spectrophotometer. The standard calibration curve was plotted using gallic acid, from which total phenolic content was expressed as the percentage $(\mathrm{w} / \mathrm{w})$ gallic acid equivalents of extracted fraction [26].

\section{Antioxidant activity}

Superoxide anion radical-scavenging activity

To $0.5 \mathrm{~mL}$ of different concentration of extracts and standard butylated hydroxytoluene (BHT) (200-1000 $\mu \mathrm{g}), 1 \mathrm{~mL}$ of alkaline dimethyl sulfoxide, and $0.2 \mathrm{~mL}$ nitroblue tetrazolium $20 \mathrm{mM}(50 \mathrm{mg}$ in $10 \mathrm{~mL}$ phosphate buffer $\mathrm{pH}$ 7.4) were added. The absorbance was measured at $560 \mathrm{~nm}$. The experiment was performed in triplicate [27]. 


\section{Nitric oxide inhibition activity}

About $1 \mathrm{~mL}$ of sodium nitroprusside solution ( $10 \mathrm{~mm}$ ) was mixed with $1 \mathrm{~mL}$ of test extract/ascorbic acid $20(\mu \mathrm{g})$ in phosphate buffer $(\mathrm{pH} 7.4)$. The test extracts were prepared in different concentrations (200$1000 \mu \mathrm{g}$ ). The aliquots were incubated at $25^{\circ} \mathrm{C}$ for $150 \mathrm{~min}$. To $1.5 \mathrm{~mL}$ of the incubated solution, $1 \mathrm{~mL}$ of Griess' reagent ( $1 \%$ sulfanilamide, $2 \%$ o-phosphoric acid, and $0.1 \%$ naphthyl ethylenediamine dihydrochloride) was added. Absorbance was read at $546 \mathrm{~nm}$ and percentage inhibition calculated. The nitric oxide radicals scavenging activity was calculated, according to the following equation:

$$
\% \text { Inhibition }=100 \times A_{\text {blank }}-A_{\text {sample }} / A_{\text {blank }}
$$

RSC = Radical scavenging capacity. $A_{\text {blank }}=$ Absorbance of a blank. $A_{\text {sample }}=$ Absorbance of a sample. BHT was used as a positive control. From the obtained RSC values, the inhibitory concentration $\left(\mathrm{IC}_{50}\right)$ values were calculated, which represents the concentration of the scavenging compound that caused 50\% neutralization [28].

\section{The $\beta$-carotene/linoleic acid antioxidant activity}

$\beta$-carotene bleaching method measured the ability of an antioxidant to inhibit lipid peroxidation. In this method, $\beta$-carotene and linoleic acid go through a quick discoloration in the absence of an antioxidant. $1 \mathrm{~mL}$ of $\beta$-carotene solution in chloroform (2 $\mathrm{mg}$ in $10 \mathrm{~mL}$ ) was pipetted into a round bottom flask containing $40 \mu \mathrm{L}$ of linoleic acid and $500 \mu \mathrm{L}$ of Tween 20. After the removal of chloroform using a rotary vacuum evaporator at $45^{\circ} \mathrm{C}, 100 \mathrm{~mL}$ of deionized water was added with vigorous agitation. A $2 \mathrm{~mL}$ aliquot of the emulsion was added to each test tubes containing various concentrations of test agents. The absorbance was measured at $470 \mathrm{~nm}$ immediately against a blank consisting of the emulsion without $\beta$-carotene and after $3 \mathrm{~h}$ of incubation at $50^{\circ} \mathrm{C}$. All determinations were carried out in quadruplicate. The antioxidant activity of test agents was evaluated in terms of bleaching of $\beta$-carotene using the following formula:

$$
A A=\left[1-\left(A_{0}-A_{t}\right) /-\left(A_{0}^{1}-A_{t}\right)\right] \times 100
$$

Where: $\mathrm{A}_{0}$ and $\mathrm{A}^{1}{ }_{0}$ are the absorbance measured at 0 time of incubation for the test sample and control, respectively, and $A_{t}$ and $A_{0}^{1}$ are the absorbance measured in the test sample and control, respectively, after $3 \mathrm{~h}$ of incubation [29].

\section{RESULTS AND DISCUSSION}

\section{Preliminary phytochemical screening}

Phytochemical screening of extracts of D. montana (Roxb.) leaves shows the presence of saponins, triterpenoid, steroids, flavonoids, and tannins (Table 1)

The preliminary qualitative analysis of various extracts (petroleum ether, chloroform, and ethanol) confirmed the presence of triterpenoid, steroids, saponins, flavonoids, and tannins. The TLC analysis of ethanolic extract showed the presence of six spots with different $R_{f}$ values that can be useful for further isolation (Table 2 and Fig. 1).

\section{HPTLC fingerprinting}

Ethanolic extract of leaves of $D$. montana (Roxb.) showed 10 spots at the maximum $R_{f} 0.02,0.07,0.11,0.2,0.29,0.39,0.44,0.66,0.83$, and
0.93. Table 3 and Fig. 2 depicts the presence of at least 10 different components in the ethanolic extract. It is also clear from Table 3 and the chromatogram as shown in Fig. 2 that out of 10 components, the components with $R_{f}$ values $0.29,0.39,0.44,0.88$, and 0.93 at $366 \mathrm{~nm}$ were found to be more predominant (percentage area is more with $24.82 \%, 22.37 \%, 16.87 \%, 14.17 \%, 11.46 \%$, and $8.36 \%$, respectively) and remaining components were found to be very less in quantity (percentage area for all the spots was $\leq 1.77 \%$ ). Thus, the developed chromatogram will be specific with selected solvent system cyclohexane:ethyl acetate $(80: 20), R_{f}$ value serves the better tool for standardization of the drug. Characteristic TLC/HPTLC fingerprinting of particular plant species will not only help in the identification and quality control of a particular species but also provide basic information useful for the isolation, purification, characterization, and identification of marker chemical compounds of the species. Thus, the present study will provide sufficient information about the therapeutic efficacy of the drug and also in the identification, standardization, and quality control of the medicinal plant.

\section{Total flavonoid contents}

The result of total flavonoid contents of crude extracts of $D$. montana (Roxb.) leaves is given in Fig. 3 total flavonoid contents of extracts are shown in Table 4. Among the two crude extracts, the ethanolic extract contains highest $(1.83 \pm 0.38 \mathrm{mg} / \mathrm{g})$ amount of flavonoids containing compounds followed by ethyl acetate $(1.48 \pm 0.51 \mathrm{mg} / \mathrm{g})$, that is, quercetin/g weight. Based on this study, we proposed that the potent free radical-scavenging and antioxidative activity of medicinal plant might result from its high contents of flavonoid type compounds.

\section{Total phenolic content}

The total phenolic contents of D. montana (Roxb.) leaves extracts were determined using the Folin-Ciocalteu's reagent. The values obtained for the concentration of total phenols are expressed as mg of GA/g of

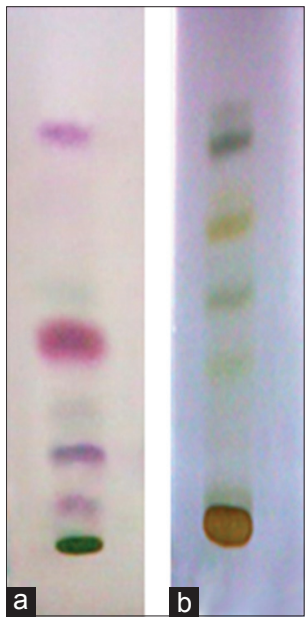

Fig. 1: Thin-layer chromatography profile of ethanolic and petroleum ether extract of $D$. montana. (Roxb.) leaves. (a) Ethanolic extract and (b) petroleum ether extract

\begin{tabular}{|c|c|c|c|c|}
\hline Phytochemicals & $\begin{array}{l}\text { Petroleum ether } \\
\text { extract }\end{array}$ & $\begin{array}{l}\text { Chloroform } \\
\text { extract }\end{array}$ & $\begin{array}{l}\text { Ethyl acetate } \\
\text { extract }\end{array}$ & $\begin{array}{l}\text { Ethanol } \\
\text { extract }\end{array}$ \\
\hline Carbohydrates & + & + & - & + \\
\hline Glycosides & - & - & + & - \\
\hline Phytosterol and steroids & + & + & + & - \\
\hline Triterpenoids & + & - & + & + \\
\hline Tannins and phenolics & + & - & - & + \\
\hline Alkaloids & - & - & - & - \\
\hline
\end{tabular}

Table 1: Qualitative phytochemical analysis of D. montana (Roxb.) leaves

+: Present, -: Absent, D. montana: Diospyros montana 


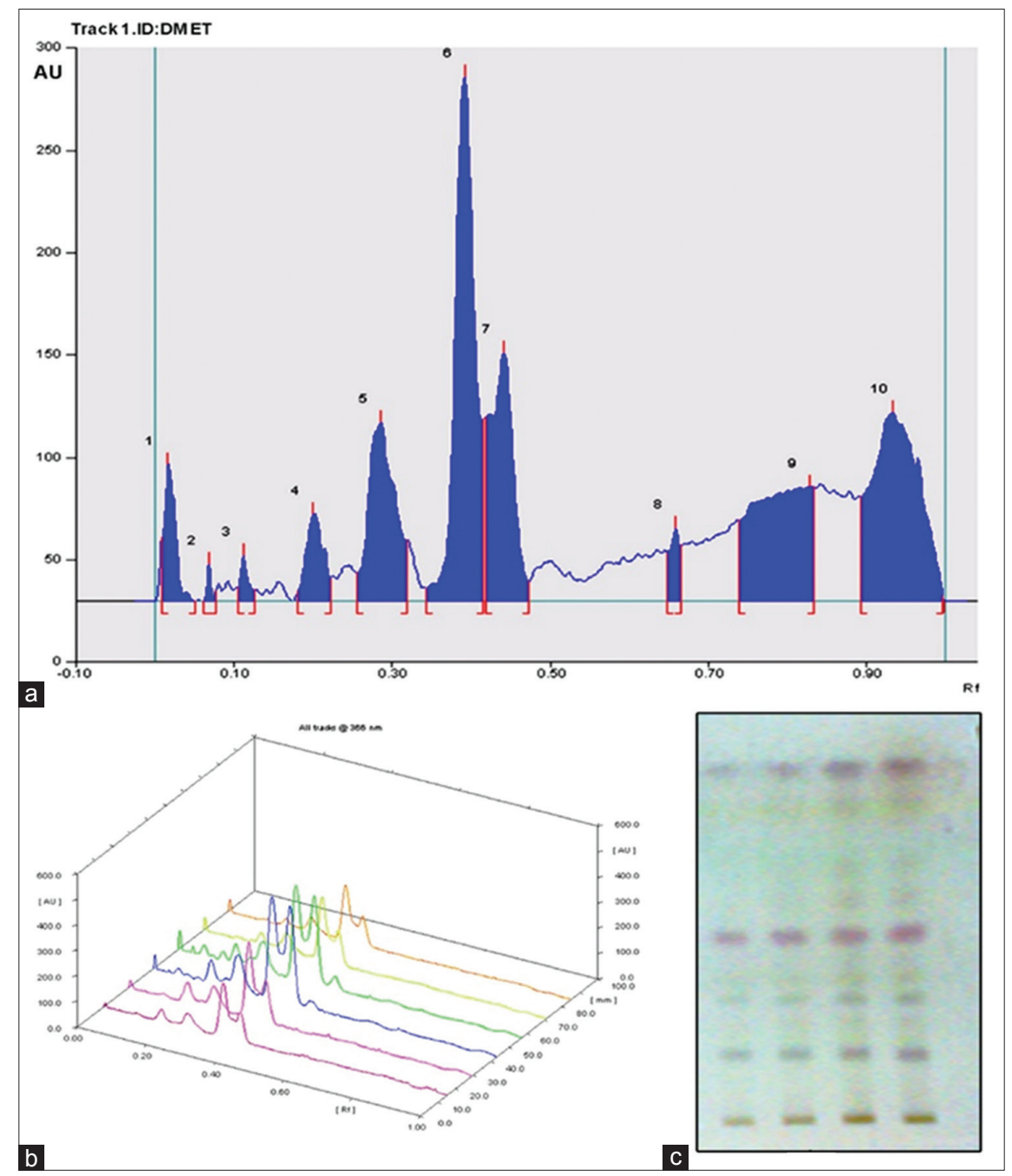

Fig. 2: High-performance thin-layer chromatography chromatogram of an ethanolic extract of Diospyros montana (Roxb.) leaves. a) HPTLC finger printing of ethanolic extract of $D$. montana leaves , b) HPTLC three-dimensional evaluation, c) HPTLC photo documentation of ethanolic extract of $D$. montana leaves

Table 2: TLC profile of ethanolic extract of $D$. montana (Roxb.) leaves

\begin{tabular}{llll}
\hline Extract & Color of spots & Spots & R $_{\mathrm{f}}$-value \\
\hline Solvent system cyclohexane:ethyl acetate (80:20) & & \\
Ethanolic & Green, blue, purple, violet brown, pale yellow & 5 & $0.29,0.42,0.48,0.62,0.85$ \\
Chloroform & Green, blue & 2 & $0.26,043$ \\
Ethyl acetate & Blue, purple, violet brown, pale yellow & 6 & $0.42,0.54,0.58,0.63,0.78$ \\
Solvent system petroleum ether: benzene (40:10) & & \\
Ethanolic & Green, blue, purple, violet brown, pale yellow & 9 & $0.23,0.29,0.38,0.43,0.56,0.63,0.78$ \\
Petroleum ether & Green, brown, purple & 3 & $0.43,0.64,0.78$ \\
\hline Spray reagent: Anisaldehyde sulfuric acid, R: Retention factor, D. montana: Diospyros montana, TLC: Thin-layer chromatography
\end{tabular}

Table 3: HPTLC fingerprinting of ethanolic extract of D. montana (Roxb.) leaves

\begin{tabular}{|c|c|c|c|c|c|c|c|c|c|c|}
\hline Track & Peak & Start $\mathbf{R}_{\mathrm{f}}$ & Start height & Maximum $\mathbf{R}_{\mathrm{f}}$ & Maximum height & Maximum \% & End $R_{f}$ & End height & Area & Area \% \\
\hline 1 & 1 & 0.01 & 31.3 & 0.02 & 67.10 & 8.37 & 0.05 & 0.20 & 833.9 & 3.24 \\
\hline 1 & 2 & 0.06 & 0.00 & 0.07 & 18.10 & 2.26 & 0.08 & 5.00 & 89.8 & 0.39 \\
\hline 1 & 3 & 0.1 & 6.70 & 0.11 & 22.40 & 2.8 & 0.12 & 5.40 & 192.7 & 0.84 \\
\hline 1 & 4 & 0.18 & 4.80 & 0.20 & 42.90 & 5.36 & 0.22 & 11.0 & 838.9 & 3.67 \\
\hline 1 & 5 & 0.26 & 13.80 & 0.29 & 87.70 & 10.94 & 0.32 & 29.8 & 2620.1 & 11.46 \\
\hline 1 & 6 & 0.34 & 6.20 & 0.39 & 256.5 & 32.03 & 0.41 & 88.60 & 5676.9 & 24.82 \\
\hline 1 & 7 & 0.42 & 89.90 & 0.44 & 121.5 & 15.17 & 0.47 & 10.0 & 3240 & 14.17 \\
\hline 1 & 9 & 0.74 & 39.30 & 0.83 & 56.10 & 7.01 & 0.83 & 55.90 & 3858.8 & 16.87 \\
\hline 1 & 10 & 0.89 & 51.10 & 0.93 & 92.60 & 11.56 & 1.00 & 2.60 & 5115.9 & 22.37 \\
\hline
\end{tabular}

Max: Maximum, $\mathrm{R}_{\mathrm{f}}$ Retention factor, D. montana: Diospyros Montana, HPTLC: High- performance thin-layer chromatography 
extract (Fig. 4.). Here, ethanolic extract showed highest (46.4 mg/g) amount of phenolics containing compounds whereas ethyl acetate extract showed slightly lower amount $(41.4 \mathrm{mg} / \mathrm{g})$ as compared to gallic acid $(76.8 \mathrm{mg} / \mathrm{g})$. These indicate a complete profile of the antioxidant activity of extracts of plants with respect to their phenols content.

\section{Antioxidant activity}

Superoxide anion radical-scavenging activity

Superoxide radical scavenging activity of $D$. montana (Roxb.) leaves extracts was compared with standard ascorbic acid and BHT. Ethanolic extract and ethyl acetate fraction both showed potent antioxidant activity compared to BHT. The hydroxyl radical scavenging activity

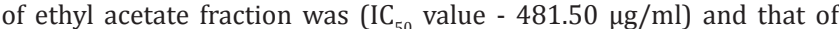
standard BHT was $\left(\mathrm{IC}_{50}\right.$ value $\left.497.60 \mu \mathrm{g} / \mathrm{m} 1\right)$ depicted (Table 5). The reduction of total oxidation products as a function of the volume of the extract added to the assay. This result implied that the potential antioxidant capabilities imparted to D. montana (Roxb.) leaves can be attributed to the presence of phenolic compounds in these species.

\section{Nitric oxide radical scavenging activity}

Ethanolic extract, petroleum ether, chloroform, and ethyl acetate fractions of D. montana (Roxb.) leaves were evaluated for antioxidant activity using in vitro models such as nitric oxide radical scavenging activity. BHT was used as standard drugs. Extracts displayed a significant nitric oxide scavenging activity at all the concentrations. Ethanolic extract and ethyl acetate fraction both showed potent antioxidant activity as compared to BHT (Table 6). It was also observed that the $\mathrm{IC}_{50}$ values of ethanolic $\left(\mathrm{IC}_{50}\right.$ $324.09 \mu \mathrm{g} / \mathrm{mL}$ ) ethyl acetate fraction $\left(\mathrm{IC}_{50} 361.11 \mu \mathrm{g} / \mathrm{mL}\right.$ ) and that of standard BHT ( $\left.\mathrm{IC}_{50} 336.99 \mu \mathrm{g} / \mathrm{mL}\right)$, respectively.

\section{Antioxidant activity in $\beta$-carotene/linoleic acid emulsion}

In the $\beta$-carotene bleaching assay of different extracts of $D$. montana (Roxb.) leaves showed variable antioxidant activities as compared to that of BHT at the concentration of $40 \mathrm{mg} / \mathrm{L}$. The antioxidant activities

Table 4: Total flavonoid content of D. montana (Roxb.) leaves

\begin{tabular}{ll}
\hline Extracts & Total flavonoid content $(\mathbf{m g ~ Q E} / \mathbf{1 0 0} \mathbf{~ g})$ \\
\hline Ethanolic & 1.83 \\
Ethyl acetate & 1.48 \\
\hline
\end{tabular}

D. montana: Diospyros montana, $\mathrm{QE}$ : Quercetin equivalents of the extracts varied significantly with different concentrations (Table 7). The antioxidant activities of all the extracts gradually increased with increasing concentration of the extracts. In this assay, all

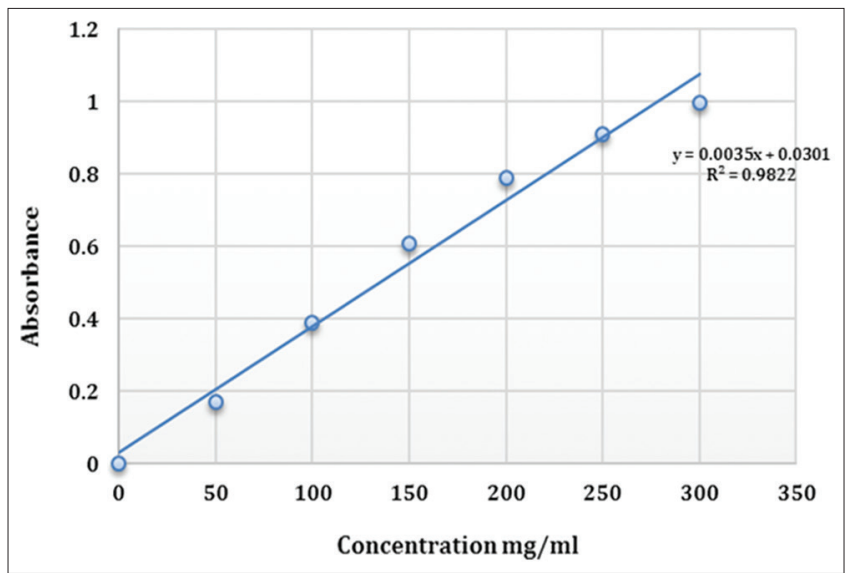

Fig. 3: Standard curve quercetin

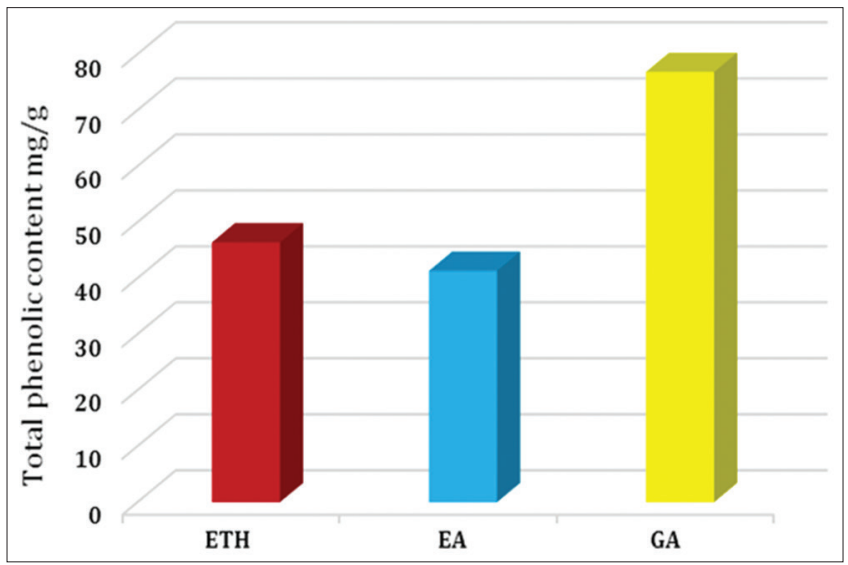

Fig. 4: Total phenolic content, ETH - ethanol extract, EA - ethyl acetate extract, and GA - gallic acid

Table 5: Super oxide radical scavenging activity

\begin{tabular}{|c|c|c|c|c|c|}
\hline $\begin{array}{l}\text { Concentration of } \\
\text { extract/standard }(\mu \mathrm{g})\end{array}$ & $\begin{array}{l}\text { (\%) Inhibition effect } \\
\text { BHT (standard) }\end{array}$ & $\begin{array}{l}\text { (\%) Inhibition effect } \\
\text { ethanolic extract }\end{array}$ & $\begin{array}{l}\text { (\%) Inhibition effect } \\
\text { pet-ether extract }\end{array}$ & $\begin{array}{l}\text { (\%) Inhibition effect } \\
\text { chloroform extract }\end{array}$ & $\begin{array}{l}\text { (\%) Inhibition effect } \\
\text { ethyl acetate extract }\end{array}$ \\
\hline 200 & 30.81 & 39.02 & 26.72 & 24.58 & 39.17 \\
\hline 400 & 42.58 & 48.32 & 38.19 & 32.51 & 45.57 \\
\hline 600 & 56.61 & 53.34 & 45.02 & 43.36 & 56.00 \\
\hline 800 & 63.81 & 63.14 & 50.51 & 55.01 & 61.500 \\
\hline 1000 & 74.55 & 71.87 & 56.00 & 58.02 & 67.90 \\
\hline $\mathrm{IC}_{50}$ value & 497.06 & 458.38 & 771.40 & 701.600 & 481.50 \\
\hline
\end{tabular}

Given values are average of triplicate, i.e., $\mathrm{n}=3$, Inhib.: Inhibition, BHT: Butylated hydroxytoluene, $\mathrm{IC}_{50}$ : Inhibition concentration (the concentration producing $50 \%$ of maximal inhibition)

Table 6: Nitric oxide radical scavenging activity

\begin{tabular}{lllll}
\hline $\begin{array}{l}\text { Concentration of } \\
\text { extract/standard }(\boldsymbol{\mu g})\end{array}$ & $\begin{array}{l}\text { (\%) Inhibition effect } \\
\text { BHT standard }\end{array}$ & $\begin{array}{l}\text { (\%) Inhibition effect } \\
\text { ethanolic extract }\end{array}$ & $\begin{array}{l}\text { (\%) Inhibition } \\
\text { effect pet-ether }\end{array}$ & $\begin{array}{l}\text { (\%) Inhibition } \\
\text { effect chloroform }\end{array}$ \\
\hline 200 & 44.38 & 43.12 & 31.56 & $\begin{array}{l}\text { (\%) Inhibition } \\
\text { effect ethyl acetate }\end{array}$ \\
400 & 52.79 & 55.21 & 38.54 & 33.38 \\
600 & 63.41 & 59.60 & 40.43 & 35.44 \\
800 & 69.71 & 63.22 & 47.12 & 39.95 \\
1000 & 74.99 & 66.73 & 51.02 & 47.60 \\
IC $_{50}$ value & 336.99 & 324.09 & 951.10 & 55.17 \\
\hline
\end{tabular}

Given values are average of triplicate, i.e., $\mathrm{n}=3$, Inhib.: Inhibition, BHT: Butylated hydroxytoluene, $\mathrm{IC}_{50}$ : Inhibition concentration (the concentration producing $50 \%$ of maximal Inhibition) 
Table 7: $\beta$-carotene/linoleic acid antioxidant activity

\begin{tabular}{llllll}
\hline $\begin{array}{l}\text { Conc. of extract// } \\
\text { standard }(\boldsymbol{\mu g})\end{array}$ & $\begin{array}{l}\text { (\%) Inhibition effect } \\
\text { BHT standard }\end{array}$ & $\begin{array}{l}\text { (\%) Inhibition effect } \\
\text { ethanolic extract }\end{array}$ & $\begin{array}{l}\text { (\%) Inhibition effect } \\
\text { pet-ether extract }\end{array}$ & $\begin{array}{l}\text { (\%) Inhibition effect } \\
\text { chloroform extract }\end{array}$ & $\begin{array}{l}\text { (\%) Inhibition effect } \\
\text { ethyl acetate extract }\end{array}$ \\
\hline 200 & 89.3 & 76.5 & 63.78 & 48.5 & 83.19 \\
400 & 88.74 & 91.21 & 70.61 & 64.5 & 99.077 \\
600 & 92.37 & 87.87 & 52.29 & 79.3 & 94.10 \\
800 & 90.642 & 93.5 & 49.75 & 78.7 & 93.25 \\
1000 & 90.122 & 89.78 & 42.12 & 88.39 & 95.5 \\
\hline
\end{tabular}

Given values are average of triplicate, i.e., $\mathrm{n}=3$, Inhib.: Inhibition. BHT: Butylated hydroxytoluene, $\mathrm{IC}_{50}$ : Inhibition concentration (the concentration producing $50 \%$ of maximal inhibition)

extracts of D. montana (Roxb.) petroleum ether showed significantly the weakest antioxidant activity while the ethyl acetate extract presented significantly the strongest activity (at all concentrations tested) in comparison to BHT. The ethyl acetate extract exhibited $83.19 \%$ antioxidant activity, respectively, at $200 \mu \mathrm{g} / \mathrm{mL}$, which was comparable to that of BHA standard at $200 \mu \mathrm{g} / \mathrm{mL}(89.3 \%)$. It is highly possible that the antioxidant components in the ethyl acetate extract can reduce the extent of $\beta$-carotene bleaching by neutralizing the linoleate free radical and other free radicals formed in the system. Their antioxidant powers were ranked in the order: BHT > ethyl acetate extract > ethanol extract > petroleum ether. The antioxidant capacity of different extracts showed the graded increase with the increase in concentration among which petroleum ether prove to be weakest (at all conc.) and ethyl acetate presented strongest antioxidant activity as compared to BHT.

\section{CONCLUSION}

The present work was embraced with a perspective to set down benchmarks which could be valuable to recognize the authenticity of this medicinally useful plant. Results obtained from the qualitative evaluation of HPTLC analysis of leaves can provide standard fingerprints and can be used as a reference for the identification and quality control of the drug. It appears that the two extracts from the leaves possess hydrogen donating capabilities to act as an antioxidant. Ethanolic extracts and its ethyl acetate fraction have significant antioxidant activity compared to petroleum ether, chloroform fraction, and well-characterized standard antioxidant systems in vitro. The various antioxidant mechanisms of D. montana (Roxb.) extract may be attributed to its strong abilities as a scavenger of superoxide and free radicals. It revealed that the extract from the leaves possesses potent antioxidant activity presumably due to its substantial amount of flavonoids and polyphenolic content of extracts. However, the components responsible for the antioxidant activity of D. montana (Roxb.) extracts are currently unclear. Further studies can be materialized toward isolation and identification of individual phenolic compounds, and also in vivo studies are needed for better understanding the mechanism of action as an antioxidant agent.

\section{ACKNOWLEDGMENT}

The author is thankful to the principal and the management of KLES's College of Pharmacy, Hubli, and Belgaum, for providing necessary facilities to carry out the research work.

\section{AUTHOR'S CONTRIBUTION}

Abhijeet Puri: Being a single author, I carried out the complete experimentation, data analysis, the inscription of a manuscript, readthrough, revising, and improving the standard of the manuscript. No other coauthor contributed to this work.

\section{CONFLICTS OF INTEREST}

The authors declare that he has no conflicts of interest.

\section{REFERENCES}

1. Puri AV, Ansari YN, Puri PA. Pharmacognostic, physicochemical and phytochemical investigation of leaves of Duranta repens Linn. Res J Pharmacogn Phytochem 2017;9:141-6.
2. Mallavadhani UV, Panda AK, Rao YR. Pharmacology and chemotaxonomy of diospyros. Phytochemistry 1998;49:901-51.

3. Priya S, Nethaji S. Antipyretic activity of ethanolic extract of leaf and bark of Diospyros Virginiana in yeast induced pyrexia. Int J Pharm Pharm Sci 2015;7:502-4.

4. Puri AV. Microscopical evaluation, phytochemical screening, and high-performance thin-layer chromatography fingerprinting of leaves of Diospyros montana (Roxb.). Int J Green Pharm 2018;12:205-11.

5. Maridass M, Ghanthikumar S, Raju G. Phytochemical analysis of Diospyros species. Ethnobot Lealf 2008;12:868-72.

6. Hazra B, Pal S, Banerjeet A, Ray R, Bhattacharya DK. Pharmacological studies on the effect of the treatment of Swiss a mice with diospyrin, a tumor-inhibitory plant product, and its synthetic derivatives. Phytother Res 1996;10:393-7.

7. Archana D, Dixitha M, Santhy K. Antioxidant and anti-clastogenic potential of Piper longum L. Int J Appl Pharm 2015;7:11-4.

8. Singh H, Dixit A, Sharma R, Sharma A. Comparative evaluation of total phenolic content, total flavonoid content and DPPH free radical scavenging activity of different plant parts of Vitex negundo. Int J Pharm Pharm Sci 2014;7:144-7.

9. Maxwell SR. Prospects for the use of antioxidant therapies. Drugs 1995;49:345-61.

10. Santharam B, Ganesh P, Soranam R, Divya VV, Lekshmi P. Free radical scavenging activity of various extracts of whole plant of Calycopteris floribunda (Lam.): An in-vitro evaluation. Int J Pharm Pharm Sci 2015;8:360-3

11. Hemnani T, Parihar MS. Reactive oxygen species and oxidative DNA damage. Indian J Physiol Pharmacol 1998:42:440-52.

12. Halliwell B. Drug antioxidant effects. A basis for drug selection? Drugs 1991;42:569-605.

13. Wolfe K, Wu X, Liu RH. Antioxidant activity of apple peels. J Agric Food Chem 2003;51:609-14.

14. Basile A, Giordano S, López-Sáez JA, Cobianchi RC. Antibacterial activity of pure flavonoids isolated from mosses. Phytochemistry 1999;52:1479-82.

15. De Flora S. Problems and prospects in antimutagenesis and anticarcinogenesis. Mutat Res 1988;202:279-83.

16. Ahmad A, Husain A, Mujeeb M, Khan SA, Alhadrami HA, Bhandari A. Quantification of total phenol, flavonoid content and pharmacognostical evaluation including HPTLC fingerprinting for the standardization of Piper nigrum Linn fruits. Asian Pac J Trop Biomed 2015;5:101-7.

17. Sharma D, Bhatia V, Patil S, Sharma PC. Antimicrobial activity of selected cryptogams from solan region. Int J Biol Pharm Res 2013;4:448-54.Moffat CA. Clarke's Analysis of Drugs and Poisons. London: Pharmaceutical Press; 2001. p. 392.

18. Atta AH, Mohamed NH, Nasr SM, Mounair SM. Phytochemical and pharmacological studies on Convolvulus fatmensis Ktze. J Natl Remedies 2007;7:109-19.

19. Shah CS, Qudry JS. A Text Book of Pharmacognosy. Ahmedabad: BS Shah Prakashan; 1989-90. p. 62-152.

20. Bruneton J. Pharmacognosy, Phytochemistry and Medicinal Plants. $2^{\text {nd }}$ ed. London: Intercept Ltd.; 1999. p. 310-54.

21. Patel JD, Kumar V. Annona squamosa L. Phytochemical analysis and antimicrobial screening. J Pharm Res 2008;1:34-8.

22. Harborne JB. A Guide to Modern Techniques of Plant Analysis. In: Textbook of Phytochemical Methods. $5^{\text {th }}$ ed. London: Chapman and Hall Ltd.; 1998. p. 91

23. Wagner H, Baldt S. Plant Drug Analysis: A Thin Layer Chromatography Atlas. $2^{\text {nd }}$ ed. Berlin: Springer; 1996. p. 196.

24. Sushma GS, Devi A, Madhulatha CH, Kumar U, Harathi P, Subramanian SN, et al. Preliminary phytochemical screening and HPTLC fingerprinting of leaf extracts of Ficus nervosa Heyne ex Roth. J Chem Pharm Res 2013;5:98-104. 
25. Hossain MA, Nagooru MR. Biochemical profiling and total flavonoids contents of leaves crude extract of endemic medicinal plant Corydyline terminalis L. Kunth. Pharmacogn J 2011;3:25-30.

26. Singleton VL, Rossi JA. Colorimetry of total phenolics with phosphomolybdic-phosphotungstic acid reagents. Am J Enol Vitic 1965;16:144-58.

27. Shreedhara CS, Aswatha RH, Zanvar SB, Gajera PF. Free radical scavenging activity of aqueous root extract of Argyreia nervosa
(Burm.I.) BoJ. (Convolvulaceae). J Nat Remedies 2006;9:216-33.

28. Mangathayaru K, Sravan K, Reddy AK, Kumar RM, Swetha B, Reddy UC. In-vitro antioxidant studies of the aerial parts of Origanum majoram Linn. and Artemesia sieversiana Ehrh. Pharmacogn Mag 2007;3:90-4

29. Habtemariam S, Jackson C. Antioxidant and cytoprotective activity of leaves of Peltiphyllum peltatum (Torr.) Engl Food Chem 2007; 105:498-503. 